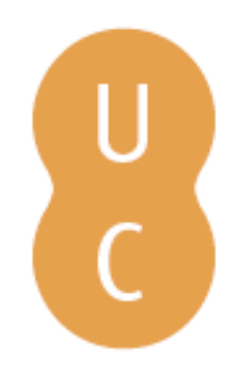

\title{
pompalina
}

\section{As Cartas Familiares: obra barroca, obra moderna}

\author{
Autor(es): $\quad$ Cunha, Mafalda Ferin \\ Publicado por: Imprensa da Universidade de Coimbra; Ediciones Universidad \\ URL \\ persistente: \\ URI:http://hdl.handle.net/10316.2/31514 \\ DOI: \\ DOI:http://dx.doi.org/10.14195/978-989-26-0245-5_10 \\ Accessed : $\quad$ 26-Apr-2023 13:43:58
}

A navegação consulta e descarregamento dos títulos inseridos nas Bibliotecas Digitais UC Digitalis, UC Pombalina e UC Impactum, pressupõem a aceitação plena e sem reservas dos Termos e Condições de Uso destas Bibliotecas Digitais, disponíveis em https://digitalis.uc.pt/pt-pt/termos.

Conforme exposto nos referidos Termos e Condições de Uso, o descarregamento de títulos de acesso restrito requer uma licença válida de autorização devendo o utilizador aceder ao(s) documento(s) a partir de um endereço de IP da instituição detentora da supramencionada licença.

Ao utilizador é apenas permitido o descarregamento para uso pessoal, pelo que o emprego do(s) título(s) descarregado(s) para outro fim, designadamente comercial, carece de autorização do respetivo autor ou editor da obra.

Na medida em que todas as obras da UC Digitalis se encontram protegidas pelo Código do Direito de Autor e Direitos Conexos e demais legislação aplicável, toda a cópia, parcial ou total, deste documento, nos casos em que é legalmente admitida, deverá conter ou fazer-se acompanhar por este aviso.

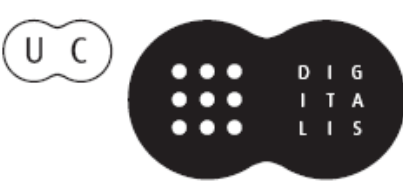


Marta Teixeira Anacleto

Sara Augusto

Zulmira Santos

Coordenação

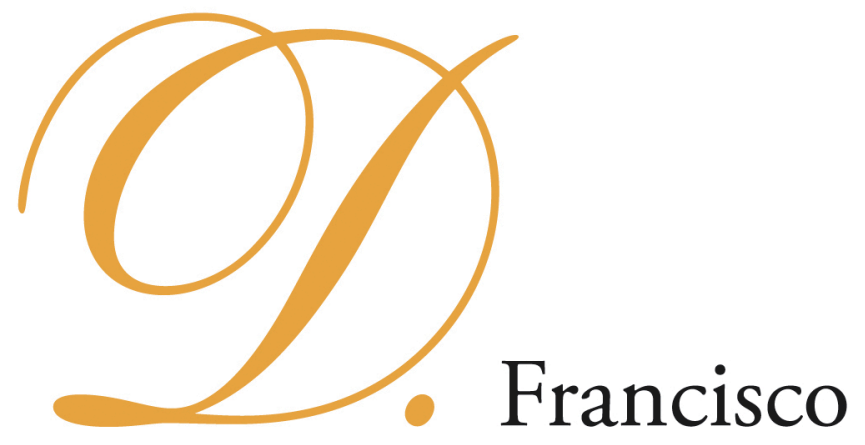

Manuel de Melo e o

Barroco Peninsular 


\title{
EDIĈ̣̃O
}

Imprensa da Universidade de Coimbra Ediciones Universidad Salamanca

\section{COORDENAÇÃo EDITORIAL}

Imprensa da Universidade de Coimbra

URL: http://www.uc.pt/imprensa_uc

Vendas online: http://www.livrariadaimprensa.com

\section{CONCEPÇÃO GRÁFICA}

António Barros

\section{REVISÃO TEXTO}

Sara Augusto

\author{
Pré-Impressão, Impressão e ACABamento \\ www.artipol.net
}

\section{IS B N}

978-989-26-0044-4 (Portugal)

978-84-7800-194-1 (Espanha)

DEPósito LEGAL

$311680 / 10$

OBRA PUBlicada COM O APOIO DE:

FCT Fundação para a Ciência e a Tecnologia

MINISTÉRIO DA CIÊNCIA, TECNOLOCIA E ENSINO SUPERIOR Portugal

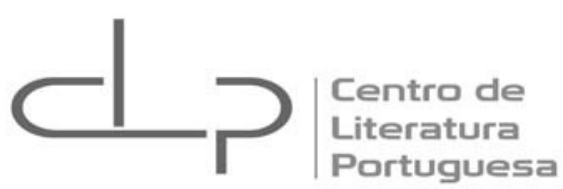

A presente publicação insere-se no Grupo "Poéticas" (coordenação de Marta Teixeira Anacleto) do Centro de Literatura Portuguesa, Unidade de I\&D financiada pela Fundação para a Ciência e a Tecnologia, ao abrigo do Programa Operacional Ciência e Inovação 2010.

(C) Agosto 2010

IMPRENSA DA UNIVERSIDADE DE COIMBRA

EDICIONES UNIVERSIDAD DE SALAMANCA 
Marta Teixeira Anacleto

Sara Augusto

Zulmira Santos

Coordenação

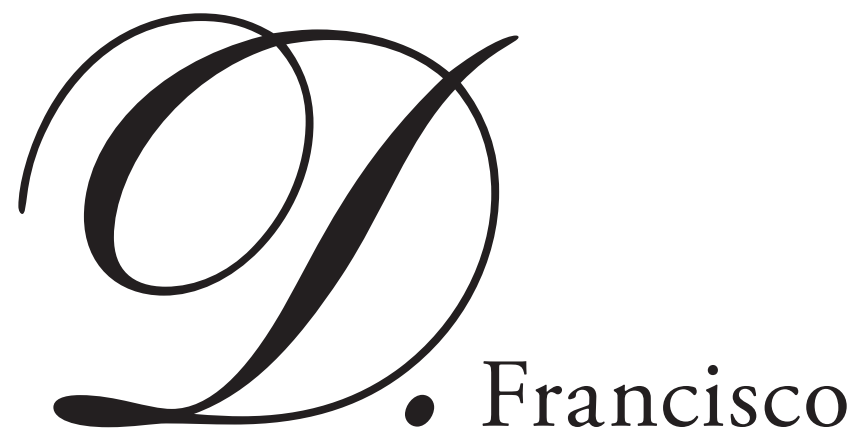

Manuel de Melo e o Barroco Peninsular

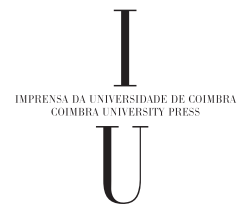


PARTE III

MODALIDADES DE ESCRITA DO BARROCO EM D. Francisco Manuel de Melo 


\section{Mafalda Ferin Cunha \\ Universidade Aberta}

\section{AS CARTAS FAMILIARES: OBRA BARROCA, OBRA MODERNA}

As Cartas Familiares de D. Francisco Manuel de Melo, editadas em Roma, em 1664, constituem o primeiro conjunto de cartas escritas em português, intencionalmente coligido e publicado sob a supervisão do seu autor.

Já antes desta data se haviam destacado outros epistológrafos portugueses, mas grande parte destes autores, que versaram essencialmente assuntos políticos, militares, geográficos, religiosos ou outros, tinha deixado as suas cartas dispersas e inéditas ${ }^{1}$. Mesmo D. Francisco de Portugal (1585-1632), poeta e autor de 114 missivas, de carácter predominantemente pessoal, dirigidas a D. Rodrigo da Cunha, náo havia publicado a sua correspondência.

O que poderá, pois, ter motivado D. Francisco Manuel de Melo e António Luís de Azevedo, o editor, a reunir e publicar, sob o nome de Cartas Familiares, cinco centúrias de epístolas do primeiro? Buscar responder a esta questão, será procurar determinar não só as funçóes que foram atribuídas à obra, no século XVII, como aquelas características que lhe terão assegurado o favor junto do público dessa época. Tentarei identificar umas e outras e, dado que estamos, hoje e aqui, ainda a lê-la e a estudá-la, buscarei também determinar o seu valor e interesse para o leitor contemporâneo.

Recuando a Petrarca e ao Humanismo, comecemos por apontar o lugar e o valor conferidos às cartas familiares no século XVII. Tendo redescoberto as Cartas Familiares de Cícero, Petrarca, ele próprio autor de uma colecção destas cartas, foi um dos principais artífices da revalorização do género epistolar, confinado, durante a Idade Média, aos rígidos códigos das artes dictaminis e a finalidades eminentemente pragmáticas associadas à actividade de chancelarias laicas e religiosas e de outros escritórios responsáveis pela emissáo de documentos. A carta surgiu então como um espaço, ainda que certamente codificado, de manifestaçáo de uma personalidade única, a do seu autor, e de apresentaçáo de uma experiência singular. Por outro lado, ao formalismo das artes dictaminis, que regulava os modos de expressão a utilizar pelos correspondentes, de acordo com as relações hierárquicas

\footnotetext{
${ }^{1}$ Andrée Rocha, na sua obra A Epistolografia Portuguesa (Lisboa: Imprensa Nacional Casa da Moeda, 2a edição, 1985, pp. 7-147), apontou nomes como o Infante D. Pedro, Frei João Álvares, Lopo de Almeida, Frei João Claro, Pêro Vaz de Caminha, Afonso de Albuquerque, D. João de Castro, Diogo do Couto, Frei Bernardo de Brito, D. Vicente Nogueira, etc..
} 
existentes entre eles, veio contrapor-se, nas cartas familiares, o uso de uma expressão coloquial, embora vigiada, que derivava, em grande parte, do modelo ciceroniano ${ }^{2}$. Acresce que, para o grande humanista italiano, se as colecçóes de cartas familiares brotavam do gozo de um relativo desafogo das árduas tarefas do homem cívico, empenhado na res publica, elas caracterizavam-se também pela inclusão de breves apontamentos filosóficos ou de reflexôes morais $^{3}$. É assim que, nas cartas familiares de Petrarca, perpassa uma marcada influência das doutrinas estóicas de Séneca (autor, igualmente, de um conjunto de cartas familiares que se impôs pelo seu valor moral, as L. Annaei Senecae Ad Lucilium Epistolae Morales), que o vate italiano faz decorrer da sua concreta experiência pessoal e da sua personalidade ${ }^{4}$.

Um pouco mais tarde, Erasmo, na sua obra De Conscribendis Epistolis, de 1522, ao traçar, como outros humanistas, uma tipologia das cartas, com base nas categorias da retórica clássica, considerou a carta como um género dúctil e proteiforme que convinha plenamente ao homem vário e à infinidade dos seus humores 5 .

Foi, certamente, devido a esta abertura do género que, entre os séculos XV e XVI, se destacaram vários e prestigiados epistológrafos. Entre eles contam-se, por exemplo, Pietro Bembo, Luís de Vives, Aldo Paolo Manúcio, Frei António de Guevara e Justo Lípsio, os dois últimos bastante conhecidos e citados por D. Francisco Manuel de Melo. Frei António de Guevara publicou, em 1542, as suas Epistolas Familiares, obra que, embora escapando, muitas vezes, ao tom despreocupado e coloquial que se esperava de um conjunto de cartas assim intitulado, constituiu um largo sucesso, tanto em Espanha, como na Europa, e Justo Lípsio iniciou, em 1586, a publicação das suas cartas, cujo bom acolhimento se deve associar não só ao valor moral das suas consideraçôes assentes nas doutrinas estóicas, como à revalorização da prosa de Séneca a partir de meados do século XVI ${ }^{6}$.

É preciso não esquecer, neste processo de redescoberta e de alargamento das potencialidades da carta, que, a par da produção de textos literários no domínio da epistolografia, outras obras e instituiçóes, como os numerosos secretários, principalmente de origem italiana e espanhola, que circularam na Europa entre os séculos XVI e XVII ${ }^{7}$, e os colégios de jesuítas, contribuíram para a divulgação da prática epistolar. Nestes últimos, onde se formaram muitos homens de corte (como foi o caso de D. Francisco Manuel de

\footnotetext{
${ }^{2}$ Gonzalo Pontón, Correspondencias. Los origenes del arte epistolar en España. Madrid: Biblioteca Nueva, 2002, pp. 39-43.

${ }^{3}$ Gonzalo Pontón, op. cit., pp. 188-189.

${ }^{4}$ Ugo Dotti, «Introduction» in Pétrarque. Lettres Familières. Paris: Les Belles Lettres, 2002, pp. XXXVIIXXXIX.

${ }^{5}$ Marc Fumaroli, «Genèse de l'épistolographie classique: rhétorique humaniste de la lettre, de Pétrarque a Juste Lipse», Revue d'Histoire Littéraire de la France. Paris, no 6 (Juillet / Aout 1978) pp. 888-890.

${ }^{6}$ Karl Alfred Blüher, Séneca en España. Investigaciones sobre la Recepción de Séneca en España desde el Siglo XIII hasta el Siglo XVII. Versión española de Juan Conde. Madrid: Editorial Gredos, 1983, pp. 405-407. Marc Fumaroli, op. cit., pp. 894-899, reforça esta ideia, ao considerar que Justo Lípsio, afirmando, como Erasmo, o principio da espontaneidade e da manifestação de uma individualidade na redacçáo das cartas familiares, cultivou, nas suas epístolas, um estilo onde se manifestam, simultaneamente, traços de ensaiada eloquência, marcas da linguagem oral corrente e figuras que preludiam o discurso engenhoso.

${ }^{7}$ Estes textos chegaram também a Portugal. Ver José Adriano de Carvalho, nota 7 ao Diálogo III de Corte na Aldeia de Francisco Rodrigues Lobo. Lisboa: Editorial Presença, 1992, p. 95.
} 
Melo, estudante em Santo Antão), a aprendizagem da redacção de missivas fazia parte das matérias curriculares, seguindo os modelos clássicos de Cícero, para as cartas familiares, e de Séneca, para as cartas morais ${ }^{8}$.

Por último, no que diz respeito concretamente a Portugal, há que fazer referência aos diálogos II e III da Corte na Aldeia (1619), de Rodrigues Lobo, dedicados à redacção de cartas. Neste texto, a prática epistolar é encarada como o correspondente escrito da arte de conversar, que deve ser apanágio do cortesáo discreto, polido, amável e agradável (por isso se procura caracterizar a "carta cortesã e bem escrita", configurada de acordo com o modelo de coloquialidade proposto por alguns humanistas ${ }^{9}$ ), e, ainda, como uma técnica a adquirir pelo homem político, em sentido lato, que pretende estabelecer e firmar relaçóes sociais com outros homens ${ }^{10}$.

Em suma, desde o Humanismo, e por uma convergência de diversos motivos, que o género epistolar se via renovado, enriquecido e prestigiado. A iniciativa de António Luís de Azevedo e de D. Francisco Manuel de Melo só pode ser plenamente entendida tendo em conta este pano de fundo, mas vejamos concretamente que motivos ambos apontaram para a recolha e a publicação das Cartas Familiares.

António Luís de Azevedo, ao dirigir-se, no início da obra, à Academia dos Generosos de Lisboa, aponta, como motivo de interesse do livro que organizou, a sua novidade («aquela [maravilha] de ser o único livro de cartas que se publicou em nosso idioma», Cartas Familiares, p. $48^{11}$ ), aspecto a relacionar com a observação que, logo adiante, faz aos Discretos: «Vi primeiro muitos volumes de Cartas que escreveram os antigos e modernos, assi latinos, como italianos e espanhóis e franceses. Confesso que nenhũas me pareceram melhores» ${ }^{12}$. Ou seja, para o editor, as cartas de D. Francisco Manuel de Melo, além de constituírem uma novidade no panorama das letras portuguesas, superam a tradição, afirmando-se como duplamente originais. Por outro lado, para António Luís de Azevedo, a obra vale enquanto retrato de um grande homem, constante no infortúnio (no que pode subentender-se o estabelecimento de uma aproximação entre a obra de D. Francisco Manuel de Melo e as epístolas de Séneca), e enquanto prática de um estilo que não é «culto», nem «enigmático», mas sim «claro, breve, sentencioso e próprio; sem afeite, sem rodeos, nem metáforas», conformando-se ao falar, de acordo com as indicaçóes de Justo Lípsio, segundo o próprio editor observa e, acrescentaria eu, de acordo com o modelo das cartas familiares de Cícero.

D. Francisco Manuel de Melo, por seu turno, valoriza as suas epístolas, na carta prévia dirigida aos leitores, enquanto testemunho da sua experiência pessoal e da sua personalidade

\footnotetext{
${ }^{8}$ Geneviève Haroche-Bouzinac, L'Epistolaire. Paris: Hachette, 1995, pp. 56-58.

${ }^{9}$ Francisco Rodrigues Lobo, op. cit., pp. 90-92 e nota 2 de José Adriano de Carvalho, na mesma obra, pp. $90-91$.

${ }^{10}$ Para tal, ele deve conhecer as regras da escrita de missivas, desde os seus aspectos exteriores (cuidados com a caligrafia, como preencher um sobrescrito, onde colocar o nome do destinatário, como o nomear, como dobrar o papel e selá-lo, etc.), à tipologia do género, sua estrutura retórica, temáticas possíveis ou aconselháveis e marcas estilísticas habituais. Ver Diálogos II e III da ediçáo citada da Corte na Aldeia.

${ }^{11}$ Todas as citaçōes das Cartas Familiares, neste trabalho, provêm da edição de Maria da Conceição Morais Sarmento (Lisboa: Imprensa Nacional - Casa da Moeda, 1981). Seguimos esta ediçẫo apenas por comodidade.

${ }^{12}$ Cartas Familiares, p. 49.
} 
e enquanto prática de um estilo assente em «frases naturais, palavras sãs e modos comuns» ${ }^{13}$, regressando também, deste modo, à coloquialidade como modelo. Para além destas palavras iniciais, na carta 303, dirigida a António Luís de Azevedo, já depois de este lhe ter sugerido a publicação das suas missivas, confessa achar-lhes «algum jeito» e aponta como critérios que poderão agradar ao público, na composição da obra, a variedade e a brevidade:

O livro vai sem ordem escrito, tendo por mais agradável aqui a variedade, e me parece que poderá levar quatrocentas epístolas, que, como as mais são breves, não fará fastioso volume. (p. 311)

É assim que, na sua primeira edição, as cartas de D. Francisco Manuel de Melo surgem agrupadas em conjuntos de cem peças, independentemente da data em que foram escritas, o que constitui uma espécie de ordenada desordem, que propicia a variedade ${ }^{14}$.

Ainda que as qualidades que o nosso polígrafo encontrou nas suas cartas, ao considerar que elas tinham «algum jeito», não tenham sido por ele esclarecidas (teriam que ver com o seu estilo? com os temas abordados? com as finalidades que poderiam servir? com o facto de revelarem o homem na sua diversidade de disposiçóes e relativa incoerência, aspectos que tinham sido apreciados por Petrarca e Erasmo, por exemplo?), das suas palavras e das de António Luís de Azevedo, pode, contudo, concluir-se que o interesse e o apreço destes homens barrocos pelas Cartas Familiares se fica a dever, em grande parte, ao facto de nesta obra se actualizarem três critérios estéticos extremamente prezados na sua época: a novidade, a variedade e a brevidade, a que podemos juntar outros que se tornam evidentes ao longo da leitura desta extensa colecção, como a sua finalidade eminentemente pragmática, associada à revalorização da retórica antiga, e a sua oscilação entre o circunstancial e particular e o universal ou paradigmático e, ainda, no que diz respeito ao estilo, as suas marcas de coloquialidade e sábio equilíbrio entre ornamento e despojamento.

Fixando-nos concretamente na obra, busquemos onde se revelam estes valores.

As Cartas Familiares de D. Francisco Manuel de Melo estabelecem laços evidentes com a tradiçáo literária acima referida. Como prova deste facto surge, de imediato, o título da colecção, que evoca as obras de Cícero, Séneca, Petrarca, Frei António de Guevara, entre outros, e que, simultaneamente, manifesta o conhecimento que o seu autor e o seu editor tinham das tipologias do género epistolar na época e das marcas atribuídas às cartas familiares $^{15}$. Mas, ao redigir e editar as suas cartas, D. Francisco Manuel de Melo não teve

\footnotetext{
${ }^{13}$ Cartas Familiares, pp. 51-52.

${ }^{14}$ Este aspecto é rasurado numa edição como a de Maria da Conceição Morais Sarmento, que ordena cronologicamente as cartas. A organização das cartas em centúrias, tal como aparece na $1^{\text {a }}$ edição, poderá resultar de uma influência de modelos alheios - as cartas de Justo Lípsio, por exemplo, estavam divididas em conjuntos de cem unidades.

${ }^{15}$ Note-se, apenas de passagem, que estas tipologias nem sempre eram inteiramente coincidentes e que podiam ser algo incoerentes, para além de que a prática as ultrapassava largamente, justapondo e amalgamando características de diversos tipos de cartas. Por exemplo, Rodrigues Lobo, na Corte na Aldeia, ao definir «carta familiar», retomando Cícero, faz equivaler as designaçôes carta familiar e carta de negócio. Por outro lado, tendo em conta o que nesta obra se diz acerca de diversos tipos de cartas, verifica-se que as Cartas Familiares de D. Francisco Manuel de Melo
} 
por objectivo primordial a imitação dos modelos consagrados, nem o ajuste das suas peças a catalogações pré-definidas ${ }^{16}$. O seu objectivo, nesta obra, foi antes, tal como afirmou no prólogo, apresentar-se como o singular e notável produto do «debuxo das fantasias da sem-razão da Fortuna», ou seja, centrar a atenção do receptor no seu retrato de ser único que retira a sua excepcionalidade de um percurso biográfico particularmente carregado de sofrimento e marcado pela injustiça.

Foi, aliás, como revelação da personalidade e experiência do seu autor que D. Francisco Manuel de Melo definiu, pela boca do Português, no Escritório Avarento, o género epistolar:

De todos os actos de entendimento nenhum é tão expresso retrato da alma, como a carta de cada um, por uma natural reverberação do espírito, que faz reflexo no papel de todos os afectos que no ânimo do homem estáo guardados e só ali circunstantes(...). ${ }^{17}$

Muito revela D. Francisco Manuel de Melo nas Cartas Familiares acerca da sua vivência única, desde os aspectos mais prosaicos, que não raro têm que ver com dificuldades económicas (é frequente que verse a pobreza e escassez do seu alimento) ou com diversas carências materiais sentidas na prisão (solicita que lhe comprem chapéus, que lhe enviem um alfaiate, que lhe tragam um pente de cana para eliminar os piolhos, etc.), às mais profundas $\mathrm{e}$ graves reflexóes sobre a sua sorte pessoal, em que oscila entre a esperança de melhoras e a amarga resignação, em tudo semelhante ao desespero. Assim, são muito significativas as comparaçóes e metáforas que D. Francisco Manuel de Melo utilizou para se pintar: Tântalo, Job, S. João Baptista (pregando no deserto), Lázaro (o pobre da parábola evangélica, que aguardava as migalhas caídas da mesa do rico), baixel na tempestade, náufrago, pássaro preso no visco, pássaro encerrado em gaiola que constantemente embate nas grades, edifício arruinado, valezinho afogado, ave de ruim agouro, cousa monstruosa (devido ao sofrimento passado), enterrado vivo. A estas se soma uma variedade de qualificativos que confirma o

englobam não só cartas de negócio como cartas entre amigos: «Três géneros de cartas missivas assina o mesmo Túlio, aos quais alguns costumam reduzir muitas espécies delas. O primeiro é das cartas de negócio e das cousas que tocam à vida, fazenda e estado de cada um, que é o que para as cartas primeiro foram inventadas, que, por tratarem de cousas familiares, se chamaram assim. O segundo, de cartas dentre amigos uns aos outros, de novas e cumprimentos de galantaria, que servem de recreaçáo para o entendimento e de alívio e consolaçáo para a vida. $\mathrm{O}$ terceiro, de matérias mais graves e de peso, como são de governo da República e de matérias divinas, de advertência a príncipes e senhores e outras semelhantes». Francisco Rodrigues Lobo, op. cit., p. 90.

${ }^{16}$ Aliás, quando D. Francisco Manuel de Melo se refere a Cícero, Séneca, Plínio o Júnior, Frei António de Guevara, ou Justo Lípsio, no decurso das suas epístolas, não é para apontar nem as marcas nem a qualidade das cartas destes autores. Por exemplo, associa Cícero ao tratamento do tema da amizade (retoma o De Amicitia, Carta 434, p. 443) e à sequência eloquência / virtude / valor cívico (citando: «Vir bonus dicendi peritus», Carta 535, p. 503); de Séneca aponta várias consideraçôes filosófico-morais (embora numa carta a António Luís de Azevedo, possivelmente a respeito das suas próprias epístolas, observe: «Guarde V. M. os lugares do Séneca, que quando chegarmos embora a impressão, eu os pedirei, como sempre...”, Carta 474, p. 465); de Frei António de Guevara aponta uma anedota por ele contada (Carta 261, p. 274).

${ }^{17}$ D. Francisco Manuel de Melo, Apólogos Dialogais, vol. II, Escritório Avarento, Hospital das Letras. Lisboa: Livraria Sá da Costa Editora, 1959, p. 53. Note-se que Justo Lípsio, na sua correspondência aos belgas, definiu a carta exactamente nos mesmos termos ( Speculum animi liber, vetus verbum fuit, sed verissime de epistolis dicetur" in Tertia ad Belgas, 1614, apud Geneviève Haroche-Bouzinac, op. cit., p. 97). 
mesmo retrato de homem sofrido e injustiçado: afligido, perseguido, assombrado, desvalido, desafortunado, encantado (por um mau feitiço, entenda-se), desgovernado, prostrado, abandonado, arruinado, despedaçado, pequenino, parvo, fraco, temerosíssimo, despido, abatido, indefeso, mísero, mofino, desditoso, confuso, morto.

Juntemos a estas afirmaçôes sobre si próprio, a forma como pintou a sua vida - desterro, martírio, tempestade, tormenta, borrasca, dilúvio, dilatada perseguição, infelicíssimo jogo, trabalho, combate, labirinto, caos - e estaremos perante o desenho nítido de um homem capaz de emocionar pelo sofrimento. Este atinge o maior paroxismo entre 1648 e 1650, anos muito conturbados na vida de D. Francisco Manuel de $\mathrm{Melo}^{18}$ e que correspondem ao maior volume de cartas recolhidas. Certo que muitas destas imagens e metáforas são recorrentes na literatura barroca e o seu uso e abuso exauriu-lhes o valor expressivo, mas, no caso de D. Francisco Manuel de Melo, a concreta e autêntica experiência biográfica de que elas decorrem e a que elas aludem confere-lhes real ressonância.

Perante este retrato, e para evitar leituras ingénuas, cumpre não esquecer que, conforme D. Francisco Manuel de Melo declarou, as Cartas Familiares representam uma selecção, feita pelo próprio autor, a partir de um número muito mais vasto de missivas ${ }^{19}$, e que as cartas publicadas foram «alimpadas» antes de virem à luz, conforme o autor afirmou na Carta 295, de 1649, dirigida a António Luís de Azevedo. Se esta operação visou eliminar nomes e referências a factos concretos que poderiam ser demasiado comprometedores (por isso grande parte dos destinatários das cartas não são nomeados), ela também terá envolvido um trabalho retórico mediante o qual o autor terá reforçado aspectos da sua personalidade e actuação, que lhe conviria acentuar, e terá modificado ou eliminado traços inconvenientes para a sua imagem pública e para os fins pragmáticos que pretendia atingir por meio da edição das cartas. Sendo o pragmatismo uma dimensão fundamental da literatura do barroco ${ }^{20}$, torna-se claro que as Cartas Familiares funcionaram como um longo discurso no âmbito do género judicial e demonstrativo, por meio do qual o autor se apresentava como um homem honesto, inteligente, sensível, culto, urbano e profundamente injustiçado, que poderia atrair a simpatia e a piedade de leitores influentes e, assim, contribuir para a sua libertação e reabilitação pública. Comprovando estas funçóes das

\footnotetext{
${ }^{18}$ Tendo sido transferido da Torre de Belém, em Lisboa, para a Torre Velha, na margem sul do Tejo, em 1646, entre 1649 e 1650 as condiçôes de prisão de D. Francisco Manuel de Melo endureceram, sendo-lhe vedados os pequenos passeios e saídas anteriormente autorizados; a sua saúde degradou-se e o fidalgo viveu momentos de profunda inquietaçáo, ou de verdadeira agonia, enquanto aguardava o resultado do seu apelo da sentença da Mesa da Consciência, recebida em 1648, pela qual vira a sua pena aumentada, confirmado o exílio para a Índia e confiscada a sua comenda. Sustentando-se de temores e esperanças, estas últimas devidas à confiança que depositava nos seus influentes amigos e numa carta de intercessão de Luís XIV, viu-se entregue ao verdadeiro tormento da espera. Finalmente, em 1650, para seu grande desespero, o Supremo Tribunal confirmou a sentença de exílio, transferido embora da Índia para o Brasil. Perdida esta causa, empenhou-se então em obter uma transferência da Torre Velha para o Castelo de Lisboa, que lhe foi concedida (Edgar Prestage, D. Francisco Manuel de Melo. Tradução do inglês por António Álvaro Dória. Coimbra: Imprensa da Universidade, 1933).

${ }^{19} \mathrm{Na}$ carta aos leitores das suas cartas, o autor afirma que redigiu, só nos primeiros seis anos da sua prisão, vinte e duas mil e seiscentas cartas (Cartas Familiares, p. 52).

${ }^{20}$ Como viu Maria Lucília Gonçalves Pires, seguindo as propostas de M. H. Abrams, é possível classificar como «essencialmente pragmática a poética barroca, tendo em conta o relevo que confere à figura do leitor e aos efeitos que a obra literária nele deve produzir», «Da poética barroca», in Xadrez de Palavras. Lisboa: Cosmos, 1996, p. 23.
} 
cartas de D. Francisco Manuel de Melo, observe-se, por exemplo, todo o afá de escrita entre os anos de 1648 e 1650. Destes anos, D. Francisco Manuel de Melo publicou mais de duzentas e cinquenta cartas datadas, dirigidas a diversos destinatários. Muitas foram enviadas a ministros, parentes, amigos, secretários, religiosos, prelados e professores, sem mais especificação. Entre os nomeados encontramos, para além de D. Ana de Áustria, Rainha Regente de França ${ }^{21}$, outras personalidades de monta, religiosos e leigos, desempenhando cargos públicos relevantes (um qualificador do Santo Oficio, bispos, juízes, embaixadores, cortesãos estreitamente ligados ao Rei, letrados, políticos, etc) ${ }^{22}$.

Foi devido a estas características e funçóes da obra que Juan Estruch Tobella considerou que as cartas familiares de D. Francisco Manuel de Melo não constituem, afinal, o espelho da alma do seu autor. Para este estudioso, o fidalgo português situou-se perante as suas epístolas como perante a sua restante obra literária, onde a efusão sentimental e a expressão do íntimo foram constantemente submetidas a um rígido controlo racional que apresenta escassas fissuras. $\mathrm{O}$ objectivo deste controlo seria apresentar ao público contemporâneo e à posteridade o retrato que D. Francisco Manuel de Melo quis difundir de si $\mathrm{mesmo}^{23}$. A justeza destas afirmaçóes é inegável, mas, no meu ponto de vista, é também inegável que nas Cartas Familiares se encontram autênticos gritos pungentes e confissóes sentidas, ainda que a par de uma quase contínua hiperbolização do infortúnio vivido pelo seu autor. Mas que homem não desesperaria e não se lamentaria perante tantos anos de prisão e demoras da justiça? Parece-me, portanto, pouco judicioso atribuir apenas a um finalidade retórica e a um simulacro de autenticidade queixas táo exactas e justificadas como a seguinte:

Não tenho já que vender, nem que empenhar, nem dinheiro para dar a barcos, nem grãos a hóspedes. Que será de mi? Estou sobretudo doente de achaques que requerem cura e neste tempo. Tenho dívidas, tenho legados a que dar satisfação. Ando em vésporas de fazer jornada larga e incerta. Que me mandem castigar no corpo, se o mereço, santo, justo

${ }^{21}$ E de D. João IV, embora a carta dirigida a este soberano não figure na primeira edição das Cartas Familiares.

22 São eles: o Padre Mestre Frei F. D. M., Qualificador do Santo Oficio da Inquisição Romana e Catedrático de Controvérsia no Colégio de Propaganda Fide, António Pereira da Cunha, Secretário do Conselho de Guerra no reinado de D. João IV, Luís da Silva Teles, Francisco de Sousa Coutinho, embaixador na Holanda e depois em França (a quem dirige quatro cartas), o Conde de Briena, Secretário de Mandamentos de D. Ana de Áustria, o Conde João Rodrigues de Sá e Meneses, Camareiro-Mor, (a quem dirige catorze cartas), Pedro da Cunha, trinchante-mor do Rei D. João IV, o Doutor Gregório de Valcaçar de Morais, Senador de Lisboa, Monsieur Lanier, residente de França em Portugal (a quem redige duas cartas), Manuel de Sousa Pacheco, o Arcediago Francisco de Sousa de Meneses (a quem dirige três cartas), o Doutor Diego Marchão Temudo, seu juiz, D. P. de Meneses, Bispo do Porto, o Doutor Juan Baptista Moreli (na verdade Frei Fulgêncio Leitão, autor do livro Reducción y Restituyción del Reyno de Portugal a la Sereníssima Casa de Bragança), João Rodrigues de Vasconcelos e Sousa, Conde de CastelMelhor (a quem dirige duas cartas), Manuel Severim de Faria, Chantre de Évora (a quem redige três cartas), o Padre Mestre Frei Timóteo de Ciabra Pimentel, primeiro jesuíta e depois carmelita (a quem escreve em duas ocasióes), o Bispo D. Frei Dionísio dos Anjos, o Bispo Capeláo-Mor D. Manuel da Cunha, D. Vicente Nogueira, Referendário Apostólico e Duarte Ribeiro de Macedo. Durante este período, redigiu ainda D. Francisco Manuel de Melo diversas cartas a António Luís de Azevedo, onde a par de notícias sobre a produção das suas obras escritas, circulam queixumes e apelos.

${ }^{23}$ Juan Estruch Tobella, «Retórica y confesión personal en las Cartas Familiares de Francisco Manuel de Melo», Arquivos do Centro Cultural Português. Lisboa / Paris: Fundação Calouste Gulbenkian, 1993, pp. 80-83. 
e bom; mas n’alma, nem na honra, nem em a conciência não parece idóneo. (Carta 357, de 1650, A um amigo, sobre negócios vários, p. 359)

Estas considerações não invalidam, de forma alguma, a constatação das evidentes finalidades pragmáticas das Cartas Familiares de D. Francisco Manuel de Melo. Toda a carta, calcada, desde as origens, sobre as categorias da eloquência e sobre os processos da retórica, espera um leitor e visa um resultado, o que, no caso deste fidalgo, encarcerado durante longos anos, se torna particularmente visível. Assim, o autor não só multiplicou epístolas e destinatários na tentativa de actuar sobre a marcha do seu processo judicial, como se serviu da carta para, simplesmente, se manter presente e interventivo na sociedade da qual se viu involuntariamente afastado. Este forte e evidente anseio de comunicar e actuar, permite compreender perfeitamente o seu patético temor de ser esquecido e a angústia dos passos onde constatou as limitaçóes de uma intervenção que depende inteiramente da palavra escrita e enviada (por exemplo, observa, em 1650, a um ministro: «Eu lhe escrevo, mas um dedo de vista vale mais que um palmo de carta», Carta 361, e a um amigo, também em 1650: «Mas esta voz clama em deserto e necessita de muitas que, se não clamarem, acordem em povoado...", Carta 306 24 ).

Consequentemente, nas cartas de D. Francisco Manuel de Melo regista-se uma ampla variedade de actos de fala: o fidalgo informa (o que é curioso; embora preso, muitas novas não lhe escapam e parece até que chegam, com relativa abundância e celeridade à prisão), julga (no que considera a distância a que se encontra do mundo ora uma vantagem - «Eu, ainda que de longe, vejo daqui, apesar dos anos e das distâncias; vejo e distingo", afirma na Carta 350, de 1650, dirigida a um secretário - ora uma desvantagem - "Quem vê de longe muitas vezes se engana», diz na Carta 263, de 1649, endereçada A um amigo ${ }^{25}$ ), formula pedidos de intercessão a favor de amigos, de protegidos ou de indivíduos de quem conhece a delicadeza da situaçáo (pede por um moço pobre e preso, por vários outros presos entregues, como ele, a justiças lentas, por militares não devidamente recompensados, por senhoras em situação vulnerável, etc.), aconselha (e gosta bastante de aconselhar noivos e recém-casados, em moldes idênticos aos da Carta de Guia de Casados, como se verifica nas cartas 313 e $347^{26}$ ), consola (e são várias as cartas de pêsames ou aquelas onde conforta os que viram o seu desempenho público insuficientemente recompensado), felicita (por ocasiáo de nascimentos, de casamento, de subida a novos cargos), oferece (os seus serviços, as suas obras literárias ou alguma prenda que acompanha a carta), deplora (insucessos, partidas, falecimentos), elogia (os seus benfeitores, as obras literárias de outros autores), corrige (as mesmas obras literárias), agradece (favores, visitas, cartas), desculpa-se (da falta de tempo, da impossibilidade de bem obsequiar, da incapacidade de agradecer devidamente), assim se revelando um indivíduo eminentemente sociável e um conversador nato.

Torna-se evidente, em muitos destes actos realizados nas cartas e através delas, o recurso a fórmulas de cortesia consagradas, tanto na escrita como na oralidade, entre os homens

\footnotetext{
${ }^{24}$ Cartas Familiares, p. 364 e p. 313.

${ }^{25}$ Cartas Familiares, p. 354 e p. 276.

${ }^{26}$ Cartas Familiares, pp. $316-317$ e p. 351.
} 
familiarizados com os códigos de uma sociedade galante. É verdade que a literatura de comportamento social, no contexto de uma reflexão sobre as normas de convivência, sempre conferira muita importância à prática dos gestos e cerimónias e ao regulamento das formas de saudar, receber, despedir-se, visitar, etc ${ }^{27}$, e que em obras como o Galateo Español, de Lucas Gracián Dantisco, e a Corte na Aldeia, de Rodrigues Lobo, o uso das cortesias e das fórmulas de tratamento hierárquico fora abordado no contexto das regras para a prática de uma epistolografia cortesã. Certamente que D. Francisco Manuel de Melo conhecia estas obras e seus ditames, assim como as fórmulas corteses registadas nos secretários.

Logo na carta que prefacia as Cartas Familiares, D. Francisco Manuel de Melo revela, graciosamente, aos seus leitores, que conhece e aprecia os costumes urbanos («Senhores: Assi como pede a cortesia que saíamos a receber a porta de nossas casas, com algũa cortês demonstração a nossos hóspedes, manda a urbanidade que, com algũa advertência, vamos a encontrar nossos leitores ao princípio de nossos livros» ${ }^{28}$ ) e, ao longo da sua colecção de missivas, tocando, como disse Rodrigues Lobo, pela voz do Prior, «o cantochão da cortesia, em cujo contraponto há cem mil galantarias e extremos ${ }^{29}$, o fidalgo presenteia os seus destinatários com diversas expressóes de recebimento, oferta, pedido, agradecimento, desculpa e despedida que primam pelo uso de encarecimentos.

Vejamos algumas destas fórmulas, nas Cartas Familiares, onde, por vezes, por detrás do convencionalismo surgem as marcas da história pessoal e da escrita do seu autor:

De oferta:

Senhor meu: a liberdade dos presos, o dado dos escassos e a parvoíce dos discretos. (Carta 458, A um amigo, p. 456)

De pedido:

Senhor, nenhum miserável pode ser cortesão. Apenas servi ontem a V. S., já lhe vou pedir hoje que me pague. Mas por certo a paga que eu peço também é serviço; porque

\footnotetext{
${ }^{27}$ O Galateo Ovvero de Costumi (1558), de Giovanni della Casa, visou, entre outras finalidades, a formação do homem «costumato e piacevole e di belle maniere» e no Galateo Español (1593), de Lucas Gracián Dantisco, que poderá considerar-se como uma tradução e adaptação para castelhano da obra italiana, o capitulo IX é dedicado às diversas cerimónias e sua oportunidade. Entre outros aspectos, o autor focou os cumprimentos e gestos que se fazem por obrigaçáo ou devido aos merecimentos alheios, as formas de acolher visitas, de dirigir a palavra a distintos interlocutores, os beija-mãos e seu código, o uso dos títulos. Na Corte na Aldeia, obra filiada na linhagem bibliográfica dos galateos, segundo José Adriano de Carvalho (ver "A leitura de Il Galateo de Giovanni della Casa na Península Ibérica: Damásio de Frias, Lucas Gracián Dantisco e Rodrigues Lobo», Revista Ocidente, vol. LXXIX, 1970, p. 157), Rodrigues Lobo manifestou idêntica preocupação pelas regras de uma retórica que deve reger os títulos, os tratamentos, as cerimónias da mesa e dos encontros em público, a etiqueta da conversação, etc.

${ }^{28}$ Cartas Familiares, p. 51. A respeito deste acolhimento feito ao leitor no início da obra, note-se que, na Corte na Aldeia, no Diálogo XII, intitulado «Das cortesias», o prior observa que, para bem acolher uma visita, é necessário dominar os modos de recebimento, assento e despedida, afirmação que se reflecte nas Cartas Familiares não apenas «à entrada", mas em muitas missivas, tanto quando o autor enuncia a sua alegria pelo facto de estar a estabelecer uma ligação com o seu correspondente, como quando, ao terminar, oferece os seus serviços, manifesta a sua gratidão ou procede ao elogio daquele de quem se despede.

${ }^{29}$ Rodrigues Lobo, op. cit., p. 238.
} 
dar ocasião a que V. S. faça ũa cousa tão boa e justa, quem duvida que é servi-lo? (Carta 243, ao Bispo do Porto D. P. de Meneses, p. 261)

De desculpas e agradecimento:

Provei a responder a V. M. e não soube. Procurei, sequer, crer a V. M. e não posso. Que hei logo de fazer para não ficar todo ingrato e inorante? Calar-me? Isto fiz. Isso faço. Ou ao menos pedir a V. M. seja o próprio que por mi se responda. Ou náo seja tão discreto que lhe náo possamos responder. (Carta 212, A um grande letrado, p. 232)

De agradecimento:

Já houve quem dissesse que o muito obrigar era espécie de tirania. Mas para quem se acha bem no cativeiro, favor será lançar-lhe mais um grilhão. Com o ferro desta alabarda me ferrou V. M.: tanta graça se me fez na que se fez a este sargento. (Carta 350, A um Secretário, p. 354)

Como é evidente, nestas fórmulas concentram-se, de acordo com os gostos do tempo, numerosos jogos de palavras e conceitos. Por exemplo:

Sei o que de novo devo a V. S., e sei que o dever-lhe náo é novo; muito mais novo será o pagar-lhe, segundo o pouco que eu posso, e o menos que se costuma pagar grandes obrigaçôes. (Carta 469, Ao Conde Camareiro Mor, p. 462)

Meu Senhor D. N.: Um corvo há em casa da Senhora Condessa que eu julgo pomba, quando me traz estas cartas de V. S., estimadas e desejadas de mi como um ramo de oliveira, contra as fúrias do dilúvio de toda a semana; porque em verdade, que, para a fraqueza do meu espírito, já qualquer ocupaçâo é tromenta desfeita. (Carta 467, A um governador, p. 460)

As Cartas Familiares revelam, deste modo, os costumes da época e reflectem as circunstâncias particulares de que brotaram, mas repare-se que, nesta obra, do particular e preso a indivíduos, momentos e factos concretos, D. Francisco Manuel de Melo chega a reflexóes de interesse e valor universais. De facto, o fidalgo é capaz de extrair, daquilo que imediatamente observa e experimenta, consideraçóes maduras e abrangentes acerca da natureza do homem e do valor da vida humana, bem como acerca de outros temas, que, para além de se revestirem de um valor primordial na sua biografia, como a amizade ou a justiça, são sempre actuais. Noutros casos, a reflexão dirige-se para temas privilegiados no tempo do autor, como a vida na Corte (dominada por mentiras, aparências e dolos), o contraste cidade/campo (preferindo claramente D. Francisco Manuel de Melo a vida na cidade), o peso do exercício dos cargos civis e a parca recompensa pública atribuída aos honestos, a mudança (o tempo tudo altera), os poderes da Fortuna.

Partindo da sua própria experiência, D. Francisco Manuel de Melo produz também diversas reflexóes acerca do comportamento do homem afligido por contrariedades e 
infortúnios e acerca dos caminhos para a superação do sofrimento. Considera, assim, que é natural e inevitável que, perante a dor, o homem experimente primeiro uma viva dilaceração e que, só depois, busque e encontre defesas na filosofia, observação que o leva a questionar ou mesmo a negar a justeza dos fundamentos das doutrinas estóicas. Afirma, por exemplo:

Duramente (a meu ver) ou mentirosamente, quiseram os Estóicos vender-nos por constância a insensibilidade. Não diriam bem as almas de ferro com corpos de barro (...). (Carta 411, de 1650, A um ministro amigo p. 398)

A presença do pensamento de Séneca, e eventualmente de Justo Lípsio, em consideraçóes deste tipo torna-se evidente, mas D. Francisco Manuel de Melo, ainda que louvando a virtude da paciência, acerca da qual escreveu mesmo «um livrete» que não chegou a terminar $^{30}$, e o papel da razão na conduçáo dos actos humanos, acaba por considerar que os afectos, que os estóicos pretendiam controlar até ao ponto de os eliminar, constituem, afinal, a essência do homem e da humanidade («nunca tive por homem aquele que se nega aos afectos da natureza», Carta 509, A um Conde, s.d. ${ }^{31}$ ). Por outro lado, incapaz ele próprio de superar definitivamente o sofrimento pelas virtudes estritamente humanas da fortaleza e conformidade, recomenda o abandono confiante à cristá Providência Divina ${ }^{32}$.

Sobre a amizade, eixo de qualquer colecção de cartas familiares, e que, para D. Francisco Manuel de Melo, sem família próxima, afastado do mundo e necessitado de quem dele se recorde, o visite e o auxilie, assume enorme valor, a ponto de considerar, em carta dirigida a um ministro, em 1650, que "padecer no silêncio dos amigos é mais do que morrer» ${ }^{33}$, tece várias reflexões, que poderão provir de leituras directas de Cícero ou de apropriaçóes posteriores e correntes da obra deste autor ${ }^{34}$.

A amplitude temática das reflexóes de D. Francisco Manuel de Melo, bem como a diversidade de actos de fala registados nas Cartas Familiares, constituem marcas evidentes da variedade nesta obra. Uma variedade que, contudo, como o próprio autor disse na carta-prólogo, está menos nos temas («Em os assuntos há pouca variedade, porque sempre

\footnotetext{
${ }^{30}$ Cartas Familiares, p. 307.

${ }^{31}$ Cartas Familiares, p. 487.

32 Sobre senequismo na epistolografia de D. Francisco Manuel de Melo, ver Rui Manuel da Rocha Rufino, Sentir moderadamente. A influência do pensamento senequista nas Cartas Familiares de D. Francisco Manuel de Melo. Porto: Faculdade de Letras da Universidade do Porto, 1996. Tese de Mestrado em História da Cultura Portuguesa, Época Moderna Outros autores como Benjamin Nicolas Teensma em Don Francisco Manuel de Melo, 1608-1666, Inventário General de sus Ideas, Gravenhage: Martinus Nijhoff-s', 1966, pp. $43-47$ e Giacinto Manupella em "Acerca do cosmopolistismo intelectual de D. Francisco Manuel de Melo", Brasilia, Coimbra: Instituto de Estudos Brasileiros, Faculdade de Letras da Universidade de Coimbra (1961) pp. 62-63, detectaram, no conjunto da obra deste autor, dissonâncias e oscilaçóes, de acordo com as vicissitudes do seu percurso biográfico, face ao pensamento estóico em geral e de Séneca em particular. Este facto levou Rui Manuel da Rocha Rufino a falar de um senequismo vivencial ou sensibilizado.

33 Cartas Familiares, p. 315.

${ }^{34}$ Considera, por exemplo, que a amizade se estabelece entre indivíduos que partilham semelhanças, que ela deve ornar-se de muitos olhos, pois o amigo olha pelo amigo, que o verdadeiro amigo é outro eu.
} 
o humor da sorte estava fixo na melancolia $\left.{ }^{35}\right)$, do que na expressão. A dor tornou-o prolixo a respeito do seu próprio caso (afirma na Carta 292, de 1649, A um amigo grande letrado: «Veja-se agora, sendo tal o humor que me ministrou a eloquência, que tais haverão sido 2600 cartas que por conta terei escrito nos seis anos de minha prisão! São largas, são proluxas, como aquela dor que lhe serve de motivo ${ }^{36}$ ), mas a impressão de redundância, a nível temático, nas Cartas Familiares, é compensada pela diversidade de registos da língua portuguesa que nelas se encontra. De facto, ainda que D. Francisco Manuel de Melo tenha apontado como características do seu discurso as «frases naturais, palavras sãs e modos comuns", de acordo com o estilo médio ou natural da carta familiar e da carta cortesã, a verdade é que, sob o ponto de vista da língua, as epístolas do fidalgo português são bastante ricas e variadas, seja porque buscou uma adequação aos seus diversos destinatários e às circunstâncias particulares que presidiram à redacçáo de cada uma das cartas, seja porque possuía um gosto natural pela palavra e suas potencialidades expressivas, ou, ainda, porque o ágil e gracioso manuseio da língua lhe permitia, de novo, afirmar as suas qualidades de homem mundano e cortês.

Desde o tom grave e do período mais amplo à frase curta e sincrética ou elíptica, desde o gracejo malicioso ao mais amargurado, desde o uso de pregóes à velada ou descoberta citação de excertos da obra de grandes autores (portugueses e não só; entre os primeiros Bernardim Ribeiro, Sá de Miranda, Camóes, Diogo Bernardes e Fernão Mendes Pinto), desde o tom coloquial, que reproduz a conversa espontânea e que pode mesmo derrapar, deliberadamente, para o nível de língua popular, ao discurso marcado por jogos de palavras e conceitos, desde a sentença breve e lapidar ao maior prosaísmo, todos estes registos convergem nas Cartas Familiares.

Comecemos por observar que o discurso sentencioso, associado à relação circunstancial / universal, marca muitas passagens da obra. É conhecido o apreço que gozaram, durante o período barroco, formas breves como a sentença, a máxima, o aforismo e o apotegma. Estas formas, não raro ligadas a uma cultura erudita, enunciavam verdades de validade universal e atraíam a atenção e a admiração dos leitores pela sua concisão e precisão, mas também, eventualmente, pelo seu carácter elíptico ou misterioso ${ }^{37}$. Nas cartas de D. Francisco Manuel de Melo, as afirmaçóes sentenciosas pontuam o discurso que se refere a situaçóes concretamente vividas ou testemunhadas pelo autor:

Estando hoje para entrar na liteira, me deram um papel de V. M.. Não podia ser melhor o anúncio de que me espera bom ano, que começando ele, lembrando-se V. M. de mi. Se assi foram bons como são muitos os nossos anos, bem nos pudéramos mandar destes presentes. (...) Tristes de esses a quem a idade só serve de peso e não de doutrina, porque a estes, dá-lhes a dor e tira-lhes a experiência. (Carta 450, A Luís Martins de Sousa, s.d., p. 452)

\footnotetext{
${ }^{35}$ Cartas Familiares, p. 52.

${ }^{36}$ Cartas Familiares, p. 299.

${ }^{37}$ Alain Montandon, Les Formes Brèves. Paris: Editions Hachette, 1992, pp. 26-30.
} 
De características formais idênticas à sentença, a frase curta e concisa surge como outro dos registos favoritos de D. Francisco Manuel de Melo, que a utiliza com propriedade e elegância. Tal como a sentença, pode convidar o leitor à decifração daquilo que é silenciado ou meramente aludido, característica bastante prezada pela poética barroca ${ }^{38}$. Repare-se na perfeição desta carta, inteiramente construída a partir da justaposição de várias frases curtas (e que recorda, inevitavelmente, o final da Carta de Guia de Casados):

A um parente moço que se partia para a guerra

P.I. Ide com Nosso Senhor. Lembrai-vos sempre dele e de quem sois. Falai verdade. Não aprofieis. Perguntai pouco. Jogai menos. Segui os bons. Obedecei aos maiores. Não vos esqueçais de mi. E sede embora Plínio Júnior, que se tudo isto fizerdes, ainda sereis mais. Deus vos leve, defenda e traga. Torre, sábado. (p. 368)

Quanto ao rifoneiro português, há que dizer que D. Francisco Manuel de Melo o conheceu e utilizou oportunamente, revelando assim o seu gosto por mais uma forma breve, esta de carácter popular e oral e de sabor a tempos antigos. Reconhece-lhe utilidade e expressividade ("que às vozes das velhas sempre achei muita serventia»"39), e certamente valor estético, e por isso se serve dele.

Cremos que se pode aproximar este apreço por provérbios e ditos do gosto que o autor manifestou pelo uso de vocábulos relacionados com actividades manuais, agrícolas ou outras (por exemplo, esbagulhado, esbagoado, matalotagem), de plebeísmos ou formas populares (escambo, corocha, tramposo, maranha), ou, ainda, de arcaísmos (esbrabejar, por exemplo $)^{40}$. Embora não muito frequente, o recurso a estes vocábulos corresponde, possivelmente, a um desejo de cultivar e promover a riqueza da língua portuguesa, pelo que D. Francisco Manuel de Melo não enjeita também, no outro extremo da escala, o léxico requintado da literatura do seu tempo, usado, igualmente, com moderação. Deste modo, observamos que, evitando excessos e, simultaneamente, alargando o leque das formas de expressáo, D. Francisco Manuel de Melo logra uma hábil combinação entre variedade e contenção, em tudo conforme aos preceitos (mais do que à prática real) da poética barroca.

Gracejos e malícias são também um traço muito característico das Cartas Familiares e funcionam adequadamente como contraponto de queixumes e lamentos repetidos. Lembremos como o riso, associado à exploração das virtualidades da língua e à arte de desenvolver uma conversa aprazível, era apreciado e celebrado na época. Já Baldassare Castiglione tinha dedicado boa parte do Livro II da sua obra Il Cortegiano (1528) ao louvor de chistes, comentários oportunos e ditos e contos graciosos. Este autor considerou o riso um elemento importante na vida social, na medida em que amenizava situaçóes, divertia e dava provas do

${ }^{38}$ Nas palavras de António Luís de Azevedo, dirigidas aos Discretos no início da obra, a concisão, que é apanágio da língua de D. Francisco Manuel de Melo, não se confunde com a obscuridade, mas pode gerar o conceito (Cartas Familiares, pp. 50-51).

${ }^{39}$ Cartas Familiares, p. 156.

${ }^{40}$ Cabe aqui recordar as palavras de apresentação da obra de António Luís de Azevedo, que observou que o seu autor não se valeu de estrangeirismos, mas de "palavras portuguesas antigas», "usadas com mediocridade», de forma a servirem de ornato (Cartas Familiares, p. 50). 
entendimento fino e maleável dos que o provocavam e dos que compreendiam as graças. Lucas Gracián Dantisco, no Galateo Español, relacionou também riso e exploração das virtualidades da língua e observou que a gracia o donaire de um cortesão dependia largamente da sua arte de motejar no tom e momento exactos ${ }^{41}$.

São estas capacidades que D. Francisco Manuel de Melo exibe nas Cartas Familiares. Tom jocoso e gracejos são perfeitamente oportunos e adaptados aos seus destinatários. Por isso os encontramos com maior frequência e intensidade nas cartas de galantaria dirigidas a destinatárias, parentas ou religiosas, com quem se permite brincar gostosamente, e a amigos e parentes próximos. Os artifícios que provocam o riso são geralmente de três qualidades: a deformação, pelo exagero, da situaçáo referida (processo que pode conduzir à caricatura), o tratamento grave de assuntos ligeiros e os jogos de palavras assentes na homonímia e na polissemia. Aprecie-se a seguinte, dirigida a uma dama que estava doente de uma queda:

Pudera V. M. antes que caísse aconselhar-se com um caído; mas, pois caiu sem conselho, sinal é que caiu por sua vontade, e destas quedas não se dão pêsames. São perigos das alturas, quanto mais que para quem em tudo é tão alta, não há passo que não seja risco. Saia por testemunha do meu pouco espanto o meu silêncio. A lástima, que pudera obrigar-me, também me ajudou a fazer mudo. Quem lhe diz que não folguei? Olhe, por duas razóes: a primeira, porque todos os doentes querem ver doentes aos sãos; a segunda, porque do baixo não se cai. Melhor é ver a V. M. segura nas quedas, que arriscada nos voos. Não é nada disso, senão que, para o poder ver desde a baixeza deste meu estado, era necessário que decesse. Enfim, Senhora, V. M. se aquiete com haver feito seu ofício, porque ainda Domingo passado nos disse Nosso Senhor que as estrelas são as que caem e os sóis os que se escurecem, etc. (Carta 571, s.d., p. 544)

O mesmo tom jocoso domina as cartas de parabéns, por natureza mais alegres:

A um amigo de parabéns de ũa filha

Senhor, na casa de bênção antes nace a fêmea que o varão. V.M. é César mais discreto que César, que se ele queria ser César ou nada, V.M. já que não teve César, tem pouco menos que é muito mais que nada; e mais também tem nada, que muito bem nada e muito bem lograda seja. (Carta 334, de 1650, p. 340)

Mas o mais notável é que D. Francisco Manuel de Melo também é capaz de versar, em tom leve e jocoso, o seu infortúnio pessoal, fazendo rir ou sorrir ao abordar problemas tâo graves para ele como a escassez de alimento, ou a falta de cartas e visitas:

N. esteve aqui ontem com os seus três filhos, que me pareceram muito bonitos. Adivinhou (como eu lhe disse) que não tinha mais de meu que três bocados de marmelada; por isso me não trouxe os outros. (Carta 65, de 1645, A um parente, p. 107)

Já se não passará sem mortificação esta Quaresma, havendo-se passado tantos dias dela sem que eu tenha novas de V. M.. Jejum d'alma é este, e que não pouco enfraquece

${ }^{41}$ Margherita Morreale, «Estudio preliminar» ao Galateo Español de Lucas Gracián Dantisco. Madrid: Consejo Superior de Investigaciones Científicas, 1968, pp. 47-49. 
o espírito carecer daquele ar que alenta e vivifica a amizade, qual o trato. (Carta 349, de 1650, A António Luís de Azevedo, p. 352)

Observa-se, contudo, que gracejos e tom jocoso se reduzem no decurso do atormentado período de 1648 a 1650 . Os que sobram, amargurados e mordazes, ferem os que o castigam:

(...) que V. M., por sua pessoa e pelos meios que lhe forem possíveis, queira ajudar esta minha pobre pretensão, lembrando ao Senhor Secretário dirija e alembre e disponha o despacho dela, porque de outra sorte eu ficarei aqui até que o eco da trombeta do Juízo Universal nos chame a todos, e confunda, como confundirá, aos que assim me tem julgado e não acabam ainda agora. (Carta 412, de 1650, a António Luís de Azevedo, p. 407)

Versátil, D. Francisco Manuel de Melo é ainda capaz de tratar o seu sofrimento socorrendo-se da linguagem popular («receo vir com os focinhos a terra e perder o que já tenho sofrido», Carta 302, dirigida a Manuel Severim de Faria ${ }^{42}$ ) ou da língua conceituosa do tempo («Para isto só fui lembrado, para me não gozar de ser esquecido. Eis aqui, Senhor meu, a razão do meu silêncio sem razão", Carta 409, dirigida a um Professor de Boas Letras) ${ }^{43}$.

Passemos, finalmente, à brevidade, marca evidente na curta extensão da grande maioria das cartas $^{44}$ e também qualidade do discurso rápido e conciso de muitas delas, de que já falámos e que mereceu o elogio do seu editor. Esta brevidade, associada à autonomia de cada uma das cartas (característica mais evidente na primeira edição das Cartas Familiares, já que a de Maria da Conceição Morais Sarmento, adoptando o critério da ordem cronológica das epístolas, faz das peças móveis um conjunto coeso e organizado numa progressão que lembra a de um diário íntimo), cria o aspecto fragmentário da obra.

Talvez entremos aqui no campo daquilo que pode mais interessar o leitor de hoje das Cartas Familiares, não especialmente motivado para o estudo do barroco. Fragmentação, descontinuidade, ruptura, incompletude, desordem, caos, são categorias caras ao paradigma contemporâneo e susceptíveis de cativar o leitor actual. Acresce que, nesta obra, à estrutura exterior fragmentada, resultante da justaposição de cartas diversas dirigidas a diferentes destinatários, corresponde, sob o ponto de vista temático, a emergência de um sujeito que frequentemente se declara perdido de si próprio, desarticulado ou despedaçado. De facto, as Cartas Familiares não são apenas percorridas pela oscilação contínua do seu autor entre a conformação e a revolta ou entre o desengano e a esperança teimosa e resistente que mais magoa, mas também, pela pungente experiência de uma identidade perdida e de uma essência aniquilada:

\footnotetext{
${ }^{42}$ Cartas Familiares, p. 309.

43 Cartas Familiares, p. 395.

${ }^{44}$ As mais longas transbordam, quase sempre, da noção de carta familiar e são, por exemplo, aquela em que D. Francisco Manuel de Melo aborda o seu projecto de publicação de uma Biblioteca Lusitana de Autores Portugueses, a Carta 414, ou aquela onde se refere a várias antiguidades de Portugal ou curiosidades da etimologia de alguns topónimos portugueses, a Carta 431 .
} 
Ando fora de mi há muitos tempos; e agora ando sem mi (...). (Carta 259, de 1649, A um Ministro, p. 273)

Que posso eu dizer a V. M. de mi, se eu de mi não sei parte? (Carta 263, de 1649, A um amigo, p. 276)

Conceda-me V. S. licença que lhe diga tenho hoje algũa saudade de mi (que é novo ter de saudades). (Carta 296, de 1649, A um ministro, p. 303)

Eu confesso de mi que, havendo sido para pouco agora sou já para nada. Não ando gente estes dias; porém nem por isso deixam os desgostos de me tratar muito como a gente. Foram tantas neles as ocasióes de descontentamento que de todo me levaram de mi isso que de mi ainda havia. (Carta 240, de 1649, A ũa parenta sobre negócios familiares, p. 259)

Assim, se é verdade que a correspondência de D. Francisco Manuel de Melo não está animada por uma pintura do mundo na sua riqueza e variedade (como sucede, por exemplo, nas cartas do Padre António Vieira, que daqui retiram grande parte do seu interesse), o que pode desapontar os leitores contemporâneos, nela permanece vivo, nítido e actual o retrato de um homem a quem não faltou tempo para explorar os meandros do eu até à experiência da sua dissolução.

É precisamente este aspecto de desvendamento de uma personalidade única e de pintura da sua vivência do sofrimento que tem interessado os críticos mais recentes das Cartas Familiares. António José Saraiva e Óscar Lopes, Andrée Rocha e Maria da Conceição Morais Sarmento valorizaram a correspondência de D. Francisco Manuel de Melo essencialmente enquanto "documento humano de experiência de vida» ${ }^{45}$ e, pelo contrário, apontaram-lhe como pecha «as subtilezas conceptistas» ${ }^{46}$ ou o "cansativo jogo malabar [de palavras e conceitos] que nem sempre entendemos à primeira ${ }^{47}$.

Mas, para os tempos de hoje, as Cartas Familiares ganham ainda mais interesse quando, superada a mera leitura autobiográfica, D. Francisco Manuel de Melo surge como figura paradigmática do homem preso nas malhas de uma sociedade pouco justa, mas consciente da sua inalienável liberdade interior (por isso afirmou na Carta 209, de 1649, dirigida e um Ministro: «saiba, Senhor meu, que estou solto e livre; porque a alma não está na Torre Velha» e na Carta 328, de 1650, dirigida a D. João Pereira: «Crea, Senhor D. N., que se o corpo está preso entre quatro paredes (...), que o ânimo se não deixa compreender de tão limitados termos» ${ }^{48}$ ). Indo ainda mais longe, como o fez Andrée Rocha que sentiu a correspondência deste autor como uma tragédia, as Cartas Familiares

\footnotetext{
${ }^{45}$ São palavras de Maria da Conceição Morais Sarmento na Parte II do Prefácio às Cartas Familiares, p. 33.

${ }^{46}$ António José Saraiva e Óscar Lopes, História da Literatura Portuguesa, 12a ediçáo. Porto: Porto Editora,

${ }^{47}$ Andrée Rocha, op. cit., p. 146.

${ }^{48}$ Cartas Familiares, p. 230 e p. 329.
} 1982, p. 498. 
cativam e abalam, hoje, porquanto configuram «a tomada de consciência do que há de inexpugnável no homem, mesmo quando colocado perante o absurdo discricionário» ${ }^{49}$.

Por último, mantém ainda bastante actualidade, nas Cartas Familiares, o retrato do escritor produzindo e divulgando a sua obra, aspecto que tem sido destacado por todos os críticos da obra, que nela recolheram abundantes informaçôes acerca da produção de D. Francisco Manuel de Melo (datas de escrita, obras não impressas, projectos de redacção, etc).

Neste ponto, o mais interessante parece-me ser o afecto que o autor demonstra pelas suas obras (a que chama "tesouros» na Carta 187, de $1648^{50}$ ) e a íntima relação que manifesta ter com elas. Chama-lhes «suas», chama-lhes «filhos» e chama-lhes «embaixadores», designação esta que revela também, sem dúvida, a finalidade retórica que lhes conferiu. É muito curioso observar, a este respeito, todo o cuidado que D. Francisco Manuel de Melo pôs na redacção da obra D. Teodósio, que desejava oferecer a D. João IV, certamente com o fito de obter o seu perdão: preocupou-se com a qualidade das fontes a consultar e a citar, com a escolha da língua - português ou castelhano - em que a redigiria, com a composição do emblema que pretendia colocar na sua abertura, etc ${ }^{51}$. De resto, outras obras, como o Fénix de África, que enviou, com muitas expectativas, a vários correspondentes, ou a sua poesia - e refere-se muitas vezes ao Panteon, que acarinhava muito pelo facto de as suas disposiçóes interiores se harmonizarem perfeitamente com o conteúdo melancólico do poema - mereceram-lhe igualmente cuidados desvelados.

A escrita histórica ou literária não se revestiu, portanto, apenas de uma finalidade pragmática para D. Francisco Manuel de Melo. Ela serviu-lhe de consolo na melancolia e de ocupação na ociosidade ${ }^{52}$. As próprias cartas funcionaram também como consolação das suas penas, segundo explicou a um amigo a quem se dirigiu em $1649^{53}$.

Tais virtudes balsâmicas da escrita em nada afectaram a seriedade do seu trabalho de homem de letras. Para bem se documentar e para se inteirar das últimas produçóes literárias, mas também para apaziguar a sua sede de leitor, D. Francisco Manuel de Melo solicita a vários correspondentes (Francisco de Sousa Coutinho, D. Vicente Nogueira, entre outros) que lhe façam chegar obras de diverso teor, desde os tratados políticos à poesia. Com humor, pede também a D. João Pereira, no momento em que redigia a Carta de Guia de Casados, que lhe envie algumas cartas de namorados, para que possa pronunciar-se acerca de requebros ${ }^{54}$. O trabalho de redacção é moroso («Sempre escrevo, mas como risco em ũa hora o que em muitos dias debuxo, luz pouco a obra ${ }^{55}$ ) e exige tranquilidade de espírito, condição nem sempre observada na sua vida atribulada, como deixam transparecer as suas lacónicas consideraçóes acerca da escrita da obra Daniel Perseguido, que deixou inacabada:

\footnotetext{
${ }^{49}$ Andrée Rocha, op. cit., p. 148.

${ }^{50}$ Cartas Familiares, p. 211.

${ }^{51}$ Cartas Familiares, pp. 246-249.

52 Cartas Familiares, p. 248 e p. 278.

${ }^{53}$ Cartas Familiares, p. 293.

${ }^{54}$ Cartas Familiares, p. 329.

${ }^{55}$ Cartas Familiares, p. 280.
} 
«Daniel anda por aqui e eu nada por ele; pouco por tudo" ${ }^{56}$. É certo, contudo, que a vasta produção literária do fidalgo, durante os anos de encarceramento, prova a extraordinária capacidade que ele tinha de escapar, por largos momentos, às suas afliçóes pessoais.

D. Francisco Manuel de Melo revela ainda nas Cartas Familiares o olhar atento com que seguia o percurso dos seus textos desde que saíam manuscritos das suas mãos até chegarem impressos às máos dos leitores. Fala dos embaraços nos despachos das licenças do Paço, das censuras ${ }^{57}$, dos erros de impressão, das dificuldades de envio a amigos e correspondentes, do facto de ele próprio já não possuir exemplares impressos para oferecer, ou porque já todos se venderam (gastaram-se, segundo afirma, trezentos volumes de uma obra no dia em que foi publicada ${ }^{58}$ ), ou porque, diz, os perdeu («porque os perdi pelo mundo em que andei perdido muitos anos» ${ }^{59}$ ). Por outro lado, é evidente, na sua correspondência, o seu desejo de ser informado acerca da recepçáo dos seus textos. D. Francisco Manuel de Melo destinava-os ao à edificação, instrução e recreio dos seus leitores e debruçava-se atentamente sobre as críticas que lhe eram feitas.

Eis o desvendamento dos círculos da produção, circulação e recepção literária do século XVII, onde já se afirmam os mecanismos, hoje consagrados, do autor que abre as portas do seu escritório, que descreve a sua arte poética e que atende às opinióes da crítica.

Do barroco à actualidade, são, portanto, vários e aprazíveis os caminhos de leitura e análise das Cartas Familiares de D. Francisco Manuel de Melo.

\footnotetext{
${ }^{56}$ Cartas Familiares, p. 370.

${ }^{57}$ Penso que se refere de facto à censura e não a críticas dos leitores, pois escreve a um Ministro: «V. M. os deixe cortar e retalhar, que eu estou já insensível, por virtude das cicatrizes passadas» (Carta 201, de 1649, p. 221). No parágrafo seguinte, refere-se ao embaraço nos despachos do Paço.

${ }^{58}$ Cartas Familiares, p. 238. Maria da Conceição Morais Sarmento crê que se tratará do Fénix de África (nota na p. 572).

${ }^{59}$ Cartas Familiares, p. 392.
} 

Série

Documentos

Imprensa da Universidade de Coimbra

Coimbra University Press

2010

- U

C • 